\title{
Persepsi Mahasiswa IAIN Kerinci terhadap Pelaksanaan Perkuliahan Daring
}

\author{
Rhomiy Handican ${ }^{1}$, Miftahul Jannah ${ }^{2}$ Zakkya $^{3}$ \\ 1,2,3 Institut Agama Islam Negeri Kerinci \\ e-mail: handicanrhomiy@gmail.com
}

\begin{abstract}
ABSTRAK. Perkuliahan daring (online) merupakan kebijakan pemerintah yang menjadi sarana utama dalam pembelajaran ketika wabah Pandemi Covid-19. Hal ini juga diterapkan di Institut Agama Islam Negeri (IAIN) Kerinci yang mengikuti anjuran pemerintah untuk melakukan kegiatan daring yang menggunakan sarana aplikasi online, seperti whatsapp grup, zoom, google classroom, dan media aplikasi lain. Penelitian ini bertujuan untuk mengetahui persepsi mahasiswa terhadap perkuliahan daring. Selama masa pandemi terkait wabah Covid-19, mahasiswa melakukan aktivitas secara daring. Analisis data yang digunakan untuk menyelesaikan penelitian ini menggunakan metode survey skala Likert dengan total sampel adalah 51 responden yang merupakan mahasiswa Institut Agama Islam Negeri (IAIN) Kerinci. Hasil penelitian menunjukkan bahwa dalam pelaksanaan pembelajaran jarak jauh terdapat beberapa dimensi yang harus menjadi perhatian utama. Dimensi tersebut antara lain: Materi atau mode ajar, Interaksi mahasiswa, dan Suasana belajar. Disisi lain kemampuan menumbuhkan pembelajaran yang bermakna menjadi suatu hal yang urgent untuk dipenuhi. Terpenuhi seluruh aspek yang dapat mendukung dan membentuk mahasiswa yang ideal tentu sudah menjadi keharusan dan kewajiban bagi kita semua dalam menghadapi semakin kuatnya arus perkembangan teknologi informasi dan komunikasi. Oleh karena itu, penelitian ini memiliki fokus pada persepsi mahasiswa terhadap dimensi pelaksanaan pembelajaran perkuliahan online.
\end{abstract}

Kata kunci: Pandemi, Persepsi, Perkuliahan daring

\section{Pendahuluan}

Kehidupan dunia pada akhir 2019 awal Tahun 2020 dihebohkan dengan munculnya suatu penyakit menular dan mematikan yang bermula ditemukan di daerah Wuhan, China. Penyakit menular ini disebabkan oleh sindrom pernapasan akut oleh corona virus 2 (severe acute respiratory syndrome coronavirus 2 atau SARS-CoV-2). Virus itu kemudian diberi nama COVID19 atau dengan nama lengkap Coronavirus disease-2019 yang disingkat menjadi COVID-19 Virus tersebut merupakan keluarga besar dari corona virus yang dapat menyerang hewan. Penyakit ini awalnya menurut informasi dari Negara China merupakan penyakit yang berasal dari hewan yang menular ke manusia yang berada di Pasar hewan Wuhan, China, Corona menyebabkan penyakit infeksi saluran pernafasan, seperti flu, MERS (Middle East Respiratory Syndrome), dan SARS (Severe Acute Respiratory Syndrome). Sejak ditemukan virus ini telah menyebar secara luas hingga mengakibatkan pandemi global yang berlangsung hingga saat ini. Gejala COVID-19 umumnya berupa demam $38^{\circ} \mathrm{C}$, batuk kering, dan sesak nafas serta dampak paling buruk untuk manusia ialah kematian. Sampai hari ini jumlah pasien terinfeksi masih terus bertambah di seluruh dunia dan belum ditemukan vaksin untuk mencegah berkembangnya virus ini (Widiyono, 2020). 
Pandemi global ini juga merebak di hampir seluruh wilayah Indonesia pada tanggal 2 maret 2020. Hal ini membuat pemerintah Indonesia mengeluarkan beberapa inisiatif dalam merespons pandemi COVID-19 dan semua pihak yang terkait berupaya ikut berperan serta dalam mengatasinya. Pemerintah memberikan himbauan kepada masyarakat agar menjaga kebersihan diri dan lingkungan sekaligus tak banyak melakukan aktivitas di luar rumah. Oleh karena itu pemerintah akhirnya memutuskan kebijakan untuk masyarakat beraktivitas dari rumah agar menghindari diri dari kerumunan. Dengan cara ini diharapkan dapat menghindari terjangkit virus dan memutus mata rantai penyebaran virus tersebut. Keputusan pemerintah untuk memberlakukan pembatasan sosial berskala besar (PSBB) merupakan kebijakan yang dipilih dalam merespon adanya Kedaruratan Kesehatan. Undang-Undang Nomor 6 tahun 2018 menjadi dasar hukum adanya kebijakan tersebut. Dampak pandemi ini pengaruhnya sangat besar terhadap kehidupan. Salah satu dampak pandemi ini adalah pengaruh yang cukup besar terhadap aktivitas di bidang pendidikan. Ini tentu tidak hanya terjadi di Indonesia melainkan juga di seluruh dunia. Beberapa akibat dari pandemi COVID-19 terhadap dunia pendidikan yang dapat disebutkan antara lain adalah penutupan sekolah-sekolah, mulai dari pendidikan usia dini, sekolah dasar dan menengah hingga universitas dan Perguruan Tinggi. Pemerintah Indonesia melalui Kementerian Pendidikan dan Kebudayaan dan Kementerian Agama RI, mengeluarkan kebijakan dengan menerapkan kebijakan belajar dan bekerja dari rumah (Work from Home) mulai pertengahan Maret 2020 dengan sistem pembelajaran jarak jauh dan membuka platform pendidikan daring yang dapat digunakan sekolah dan guru untuk menjangkau peserta didik dari jarak jauh dan membatasi hambatan di dalam menjalankan pendidikan. Sehubungan dengan perkembangan tersebut, Kementerian Pendidikan dan Kebudayaan (Kemendikbud) turut mengambil kebijakan sebagai panduan dalam menghadapi penyakit tersebut di tingkat satuan pendidikan. (Kemendikbud, 2020).

Istilah daring merupakan akronim dari "dalam jaringan "yaitu suatu kegiatan yang dilaksanakan dengan sistem daring yang memanfaatkan internet. "Pembelajaran daring merupakan program penyelenggaraan kelas pembelajaran dalam jaringan untuk menjangkau kelompok target yang masif dan luas". "Pembelajaran daring adalah pembelajaran yang menggunakan teknologi multimedia, kelas virtual, CD ROM, streaming video, pesan suara, email dan telepon konferensi, teks online animasi, dan video streaming online". Sementara itu Rosenberg dalam Alimuddin, menekankan bahwa e-learning merujuk pada penggunaan teknologi internet untuk mengirimkan serangkaian solusi yang dapat meningkatkan pengetahuan dan keterampilan.

Daring memberikan metode pembelajaran yang efektif, seperti berlatih dengan adanya umpan balik terkait, menggabungkan kolaborasi kegiatan dengan belajar mandiri, personalisasi pembelajaran berdasarkan kebutuhan mahasiswa dan menggunakan simulasi dan permainan”. Sementara itu menurut Permendikbud No. 109/2013 pendidikan jarak jauh adalah proses belajar mengajar yang dilakukan secara jarak jauh melalui penggunaan berbagai media komunikasi.

Dari pengertian di atas, dapat disimpulkan bahwa pembelajaran daring atau e-learning merupakan suatu pembelajaran yang memanfaatkan teknologi dengan menggunakan internet dimana dalam proses pembelajarannya tidak dilakukan dengan face to face tetapi menggunakan media elektronik yang mampu memudahkan siswa untuk belajar kapanpun dan dimanapun. (Kamayanthy, 2020). 
Pandemi adalah wabah penyakit yang menjangkit secara serempak dimana-mana, meliputi daerah geografis yang luas. Pandemi merupakan epidemi yang menyebar hampir ke seluruh negara atau pun benua dan biasanya mengenai banyak orang. Peningkatan angka penyakit diatas normal yang biasanya terjadi, penyakit ini pun terjadi secara tiba-tiba pada populasi suatu area geografis tertentu. (А.М. Мамонтов, n.d.)

Coronavirus Disease (COVID-19) adalah penyakit menular yang disebabkan oleh virus corona yang baru ditemukan dan dikenal sebagai sindrom pernafasan akut atau parah virus corona 2 (SARS-CoV-2). Coronavirus Disease ialah jenis penyakit yang belum teridentifikasi sebelumnya oleh manusia, virus ini dapat menular dari manusia ke manusia melalui kontak erat yang sering terjadi, orang yang memiliki resiko tinggi tertular penyakit ini ialah orang yang melakukan kontak erat dengan pesien COVID-19 yakni dokter dan perawat. (Archika, 2020).

World Health Organization (WHO) menetapkan tentang virus corona atau yang biasa disebut dengan COVID 19 yang menjadi pandemi karena virus ini telah menyebar ke berbagai negara bahkan sudah mendunia. WHO mengartikan pandemi sebagai suatu kondisi populasi pada dunia dan berpotensi menjadikan jatuh dan sakit. Pandemi sendiri adalah wabah yang berjangkit secara bersamaan dmana-mana yang menyebar luas. Pandemi COVID 19 ini juga berdampak dari berbagai sektor kehidupan seperti ekonomi, sosial dan juga pendidikan. Organisasi Pendidikan, Keilmuan, dan Kebudayaan Perserikatan Bangsa-Bangsa atau United Educational, Scientific, and Cultural Organization (UNESCO) pada hari kamis 5 maret 2020 menyatakan bahwa wabah COVID 19 ini telah berdampak pada dunia pendidikan (Irawan, 2020).

Di Indonesia, dunia pendidikan juga ikut merasakan dampaknya. Jika kondisi seperti ini terus meningkat, maka sudah bisa dipastikan dampaknya terhadap sektor pendidikan juga akan semakin meningkat. Dampak yang paling dirasakan adalah peserta didik di instansi penyelenggara pelayanan pendidikan, seperti sekolah disemua tingkatan, lembaga pendidikan non formal hingga perguruan tinggi beradaptasi untuk belajar secara tidak langsung dalam artian secara daring.

Namun pertanyaannya adalah apakah aktifitas pembelajaran dalam perkuliahan daring memiliki nuansa yang sama atau sekurangnya mendekati dengan aktivitas perkulihan dalam pembelajaran secara tatap muka. Berdasarkan penelitian terdahulu yang dilakukan oleh Fortune, Spielman, \& Pangelinan (2011) ada beberapa masalah yang dihadapi dalam perkuliahan online antara lain: materi ajar, interaksi belajar dan lingkungan belajar. Materi ajar yang digunakan dalam perkuliahan online apakah sudah sesuai dengan kebutuhan mahasiswa?. Apakah instruksiinstruksi dalam materi ajar yang digunakan dalam perkuliahan online mudah dimengerti oleh mahasiswa? dan lain sebagainya. Interaksi belajar juga memegang peranan penting dalam proses belajar-mengajar. Bonk, Magjuka, Liu, \& Lee (2005) menjelaskan bahwa interaksi memiliki peranan penting dalam proses perkuliahan. Hal ini dikarenakan dalam proses perkuliahan perlu dibangun hubungan yang baik antara dosen dan mahasiswa agar materi yang diajarkan dapat tersampaikan secara baik. Yang terakhir adalah lingkungan belajar. Lingkungan belajar memiliki peranan penting dalam membantu mahasiswa agar merasa nyaman dan bersemangat dalam proses belajar mengajar.

Berdasarkan uraian di atas maka peneliti tertarik untuk meneliti terkait persepsi mahasiswa terhadap pembelajaran online di masa pandemi pada Institut Agama Islam Negeri (IAIN) Kerinci. Dalam penelitian ini, yang menjadi pertanyaan penelitian adalah "Apa persepsi siswa terhadap pembelajaran online tersebut?” 


\section{Metode}

Metode Likert scale survey digunakan dalam penelitian ini, yaitu dengan menyebar angket secara daring menggunakan google form kepada 51 mahasiswa Institut Agama Islam Negeri (IAIN) Kerinci. Metode tersebut digunakan karena menurut Sugiyono (2011) metode skala Likert cocok digunakan untuk mengeksplorasi persepsi mahasiswa. Metode Likert scale survey adalah metode penelitian kuantitatif untuk mendapatkan data dari sekelompok orang dengan pendekatan setuju/tidak setuju, puas/tidak puas, dan sebagainya tentang sikap, opini, tingkah laku, persepsi atau karakteristik dari orang tersebut. Dalam jenis penelitian ini, peneliti mengumpulkan data secara kuantitatif, data tersebut berupa kuesioner yang dapat dianalisis secara statistik untuk menunjukkan trend dari respon yang diberikan oleh populasi sasaran tentang fenomena yang dibahas (Creswell, 2014, 2016). Data yang didapat dan diolah dari google form tersebut disajikan dalam bentuk diagram lingkaran untuk mengetahui kecenderungan persepsi mahasiswa terhadap pelaksanaan pembelajaran online selama masa pandemi.

\section{Hasil dan Diskusi}

\section{Profil Responden}

Responden dalam penelitian ini adalah mahasiswa yang sedang menempuh jenjang perkuliahan semester genap tahun ajaran 2020/2021 di Institut Negeri Agama Islam (IAIN) Kerinci. Jumlah responden sebanyak 51 orang. Adapun data sebaran demografi responden adalah sebagai berikut:

51 jawaban

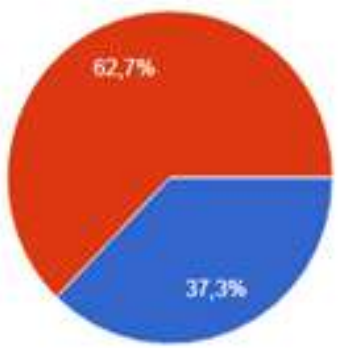

- Laki-laki

- Perempuan

Gambar 1. Profil Responden

Responden dalam penelitian ini sebagaimana ditunjukkan oleh Gambar 1 berjumlah 51 mahasiswa dengan rician 62,7\% mahasiswa perempuan dan 37,3\% mahasiswa laki-laki.

\section{Kondisi Perkuliahan Daring}

Kondisi perkuliahan daring adalah situasi yang mendukung mahasiswa dalam melaksanakan perkuliahan daring. Kondisi tersebut dapat berupa media atau alat yang digunakan untuk perkuliahan daring, kendala yang dihadapi saat pelaksanaan perkuliahan daring serta aplikasi yang digunakan saat pelaksanaan perkuliahan daring. Adapun data lengkapnya dapat dilihat pada tabel di bawah ini. 


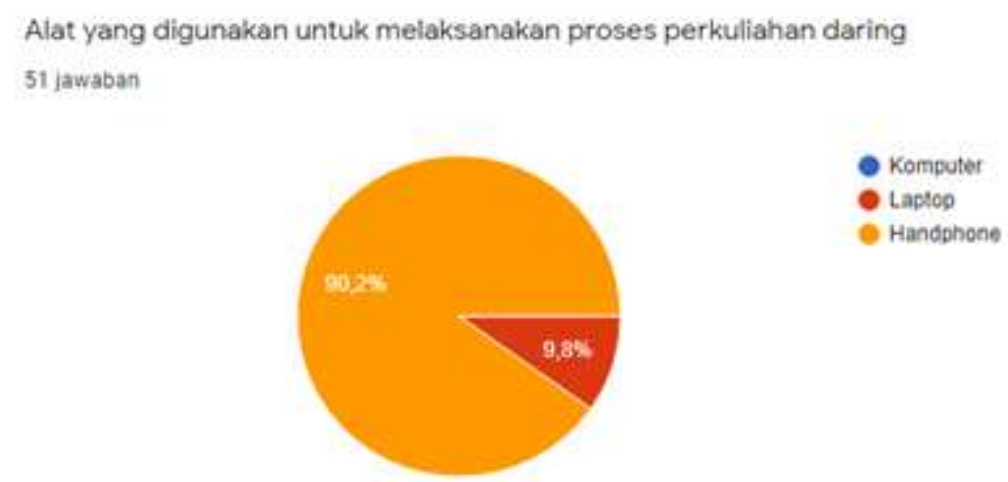

Gambar 2. Alat Perkuliahan

Gambar 2 menunjukkan bahwa alat atau device yang digunakan dalam perkuliahan daring paling banyak menggunakan Handphone atau telepon pintar yaitu sekitar 90,2\% dari total responden. Hal ini dikarenkan hampir seluruh mahasiswa telah memiliki telepon pintar dalam kesehariannya. Sebanyak 9,8\% mahasiswa yang menggunakan Laptop dan tidak ada sama sekali mahasiswa yang menggunakan Komputer.

\section{Hambatan yang dialami ketika melaksanakan proses perkuliahan daring 51 jawaban}

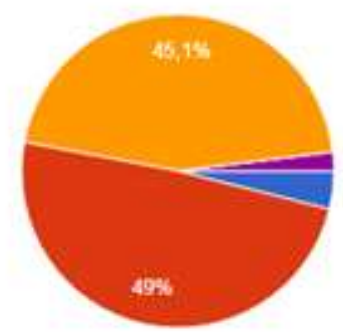

Tidak memilis perangkat (Komputer, Laptop, Handphone)

Tidak memniks kuota internet

- Jaringan internet sulit

- Kondisi kesehatan

Padamnya listrik membuat jaringan

hilang

Gambar 3. Kendala Perkuliahan

Perkuliahan dengan sistem daring yang dilaksanakan oleh mahasiswa tentunya memiliki beberapa hambatan seperti tidak memiliki alat untuk belajar, keterbatasan kuota yang dimiliki, jaringan yang sulit dan tidak stabil, kondisi kesehatan saat mengikuti perkuliahan daring serta masalah klasik yang sering ditemui yaitu padamnya listrik yang bisa membuat jaringan hilang.

Dari sekian banyak kendala yang dialami oleh responden, terdapat dua kendala yang paling banyak dialami selama perkuliahan daring, yakni tidak memiliki kuota internet atau terbatasnya kuota sebanyak 49\% . Hal ini tentunya harus menjadi perhatian, karena tidak semua mahasiswa memiliki kondisi ekonomi yang mencukupi untuk membeli kuota internet. Dalam hal ini institusi harus dapat menerapkan langkah strategis seperti halnya menyiapkan aplikasi perkuliahan daring yang menggunakan kuota rendah. Dalam penelitian yang dilakukan oleh Jamaluddin et al. (2020) cara yang paling efektif dalam menekan kuota adalah dengan menyiapkan dan menyediakan aplikasi rendah kuota. Seperti yang dilakukan oleh UIN Sunan Gunung Djati Bandung dalam menyediakan aplikasi E- Knows yang tidak memerlukan kuota besar untuk mengaksesnya. Selain itu, terdapat pelayanan berupa kuota gratis puluhan Giga Byte (GB) dengan cara kerjasama dengan provider untuk mengakses layanan pendidikan.

Hambatan berikutnya yang sering ditemui adalah jaringan internet yang sulit yaitu sebanyak 45,1\%. Jaringan sulit merupakan hambatan dalam proses perkuliahan dengan sistem daring, 
karena berkaitan dengan kelancaran proses perkuliahan. Keberadaan responden yang jauh dari pusat kota atau beberapa kota belum memiliki kualitas provider yang mumpuni tentu menjadi kendala tersendiri dalam melaksanakan proses pembelajaran dengan lancar. Hal ini juga ditemui dalam penelitian yang dilakukan oleh Jamaluddin et al. (2020) terakait pembelajaran daring masa pandemi covid 19 pada calon guru: hambatan, solusi dan proyeksi.

Hambatan berikutnya adalah tidak memiliki perangkat sebanyak 3,9\%. Padamanya listrik membuat jaringan hilang sebanyak $2 \%$ dan untuk kondisi kesehatan mahasiswa tidak ada yang terganggu selama proses perkuliahan daring berlangsung.

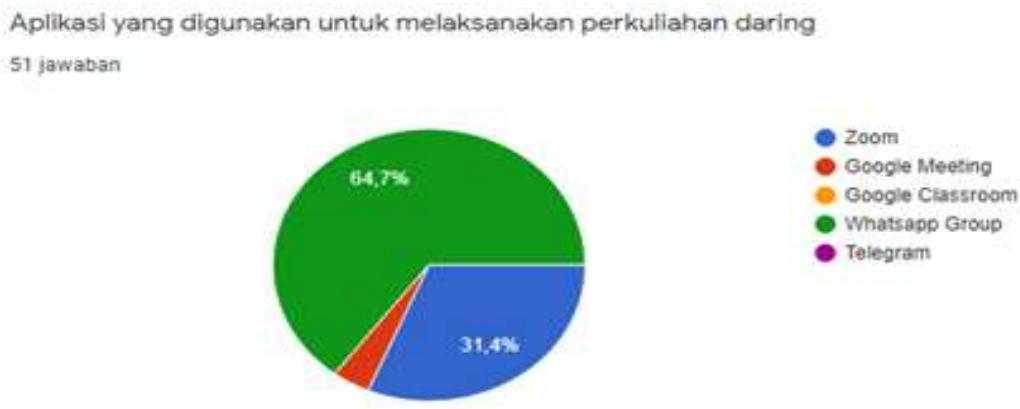

Gambar 4. Aplikasi Perkuliahan

Aplikasi merupakan salah satu tools yang dapat membantu jalannya sistem perkuliahan daring. Dalam penelitian ini, berdasarkan Gambar 4 diatas media yang paling banyak digunakan adalah aplikasi Wathshap Groups. Hal ini terliht dari responden yang memilih media belajar daring Wathshap Groups sebanyak 64,7\%. Salah satu alasan aplikasi ini banyak digunakan karena tidak menghabiskan banyak kuota mahasiswa. Disamping itu banyak kemudahan yang dilakukan, salah satunya adalah pengiriman materi bahan ajar langsung melalui grup yang telah di buat di aplikasi Wathshap. Aplikasi selanjutnya adalah Zoom Meeting sebanyak 31,4\%. Aplikasi ini memang sudah banyak dipakai oleh mahasiswa dan dosen untuk melaksankan perkuliahan daring dikarenakan bisa langsung melihat wajah teman-teman dan dosen melalui aplikasi. Google Meeting menempati posisi ketigadalam penggunaan aplikasi perkuliahan daring yaitu sebanyak 33,3\%. Sedangkan Google Clasroom dan Telegram tidak ada mahasiswa yang menggunakannya.

\section{Dimensi Materi Ajar}

Materi ajar memiliki peranan yang sangat penting dalam proses perkuliahan. Materi ajar yang disajikan harus dapat memenuhi kriteria yang ideal bagi mahasiswa diantaranya: Konten yang sesuai dengan kebutuhan mahasiswa, materi ajar yang sistematis sehingga memudahkan mahasiswa dalam mempelajarinya, dan penggunaan kosakata dan gaya penulisan yang jelas sehingga mudah dipahami oleh mahasiswa.

Secara umum, saya senang dan puas dengan mode perkuliahan daring

51 jawaban

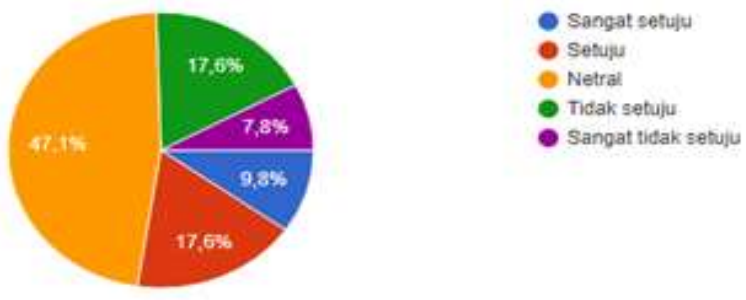

Gambar 5. Mode Perkuliahan 
Berdasarkan Gambar 5 terkait dengan mode belajar yang berhubungan dengan materi perkuliahan atas respon terhadap pernyataan, "Secara umum, Saya senang dan puas dengan mode peerkuliahan daring". Sebanyak 47,1\% mahasiswa yang menyatakan netral, 17,6\% mahasiswa yang menyatakan setuju, 17,6\% lagi mahasiswa yang menyatakan tidak setuju, 9,8\% mahasiswa yang menyatakan sangat setuju dan 7,8\% mahasiswa yang menyatakan sangat tidak setuju. Dari data yang ditampilkan tersebut, mayoritas responden menjawab netral terkait mode pembelajaran yang telah dilaksanakan dalam perkuliahan daring. Oleh karena hal tersebut, dosen sebaiknya melakukan inovasi dan variasi dalam pemberian materi ajar sehingga dapat meningkatkan minat mahasiswa dalam mengikuti pembelajaran daring.
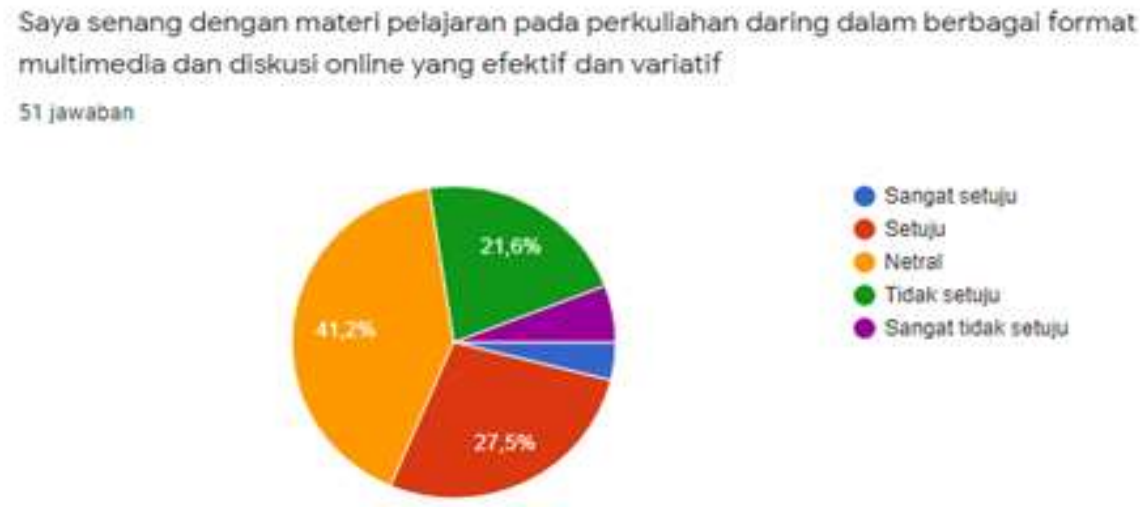

Gambar 6. Materi Pelajaran

Berdasarkan Gambar 6 terkait pernyataan: "Saya senang dengan materi pelajaran pada perkuliahan daring dalam berbagai format multimedia dan diskusi online yang efektif dan variatif'. Sebanyak 41,2\% responden menyatakan netral, 27,6\% responden menyatakan setuju, 21,6\% responden menyatakan tidak setuju, 5,9\% responden menyatakan sangat tidak setuju, dan 3,9\% responden menyatakan sangat setuju. Data menunjukkan bahwa mayoritas jawaban terkait pernyataan diatas menjawab netral. Namun di posisi kedua, responden menjawab setuju. Dalam hal ini dapat disimpulkan bahwa materi telah disampaikan dengan baik dalam bentuk multimedia dan diskuis online yang efektif dan variatif, akan tetapi dosen perlu lebih meningkatkan lagi kreatifitas dalam penyajian bahan ajar.

Perkuliahan daring ini layak mendapat apresiasi dan perhatian dikalangan mahasiswa

51 jawaban
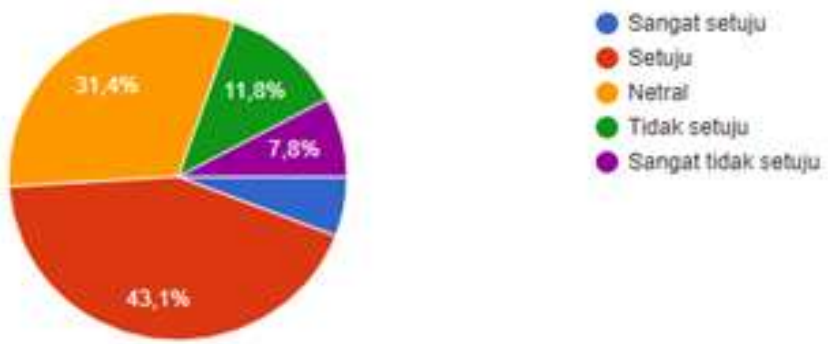

Gambar 7. Apresiasi Mahasiswa

Berdasarkan Gambar 7 terkait pernyataan: "Perkuliahan daring ini layak mendapat apresiasi dan perhatian di kalangan siswa". Sebanyak 43,1\% responden menyatakan setuju, 31,4\% responden menyatakan netral, $11,8 \%$ responden menyatakan tidak setuju, $7,8 \%$ responden yang menyatakan sangat tidak setuju dan 5,9\% responden yang menyatakan sangat setuju. Hal ini 
mengindikasikan bahwa perkuliahan daring layak mendapat apresiasi dan perhatian di kalangan mahasiswa.
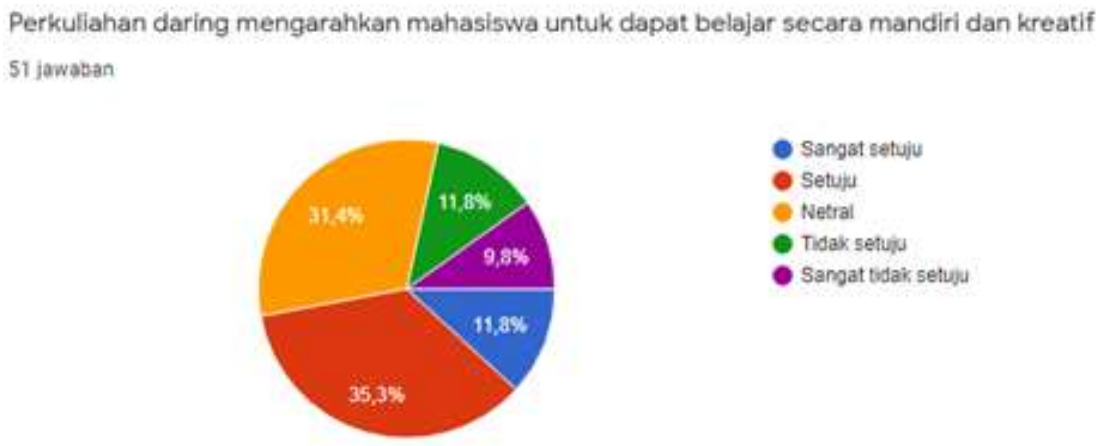

Gambar 8. Kemandirian dan Kreativitas Mahasiswa

Berdasarkan Gambar 8 terkait pernyataan: "Perkuliahan daring mengarahkan siswa untuk dapat belajar secara mandiri dan kreatif'. Sebanyak 35,3\% responden yang menyatakan setuju, $31,4 \%$ responden menyatakan netral, $11,8 \%$ responden menyatakan tidak setuju, 11,8\% responden menyatakan sangat setuju, dan $9,8 \%$ responden menyatakan sangat tidak setuju. Data ini menunjukkan bahwa mahasiswa memiliki kecenderungan menyetujui bahwasannya perkuliahan daring dapat mengarahkan mereka untuk belajar secara mandiri dan lebih kreatif.

\section{Dimensi Suasana dan Lingkungan Belajar}

Lingkungan belajar berperan sangat penting dalam proses perkuliahan untuk menciptakan suasana nyaman dan memotivasi mahasiswa dalam belajar sehingga dapat menggapai hasil belajar yang lebih baik. Lingkungan belajar menjadi salah satu bagian penting dalam membantu mahasiswa memiliki semangat belajar yang tinggi, oleh karena itu lingkungan belajar harus mampu menciptakan ketenangan serta memotivasi dalam kegiatan belajar mengajar (Radovan \& Makovec, 2015).

\section{Mahasiswa merasa terganggu dengan adanya perkullahan daring}

51 jawaban

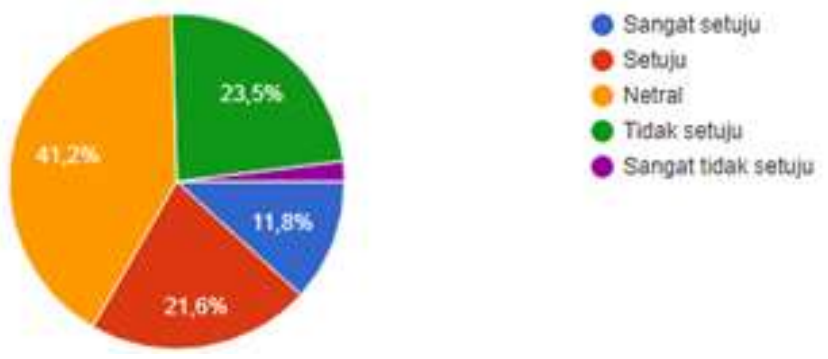

Gambar 9. Kenyamanan Mahasiswa

Berdasarkan Gambar 9 terkait pernyataan: "Siswa merasa terganggu dengan adanya perkuliahan daring terhadap aktivitas kegiatan lainnya". Sebanyak 41,2\% responden menyatakan netral, 23,5\% responden menyatakan tidak setuju, 21,6\% responden menyatakan setuju, 11,8\% responden menyatakan sangat setuju, dan $1,9 \%$ responden menyatakan sangat tidak setuju. Dari data tersebut, mahasiswa memiliki kecenderungan netral atas pernyataan yang menyatakan perkuliahan daring mengganggu aktivitas kegiatan mereka. 
Saya lebih berani dan percaya diri melalui perkuliahan secara daring

51 jawaban

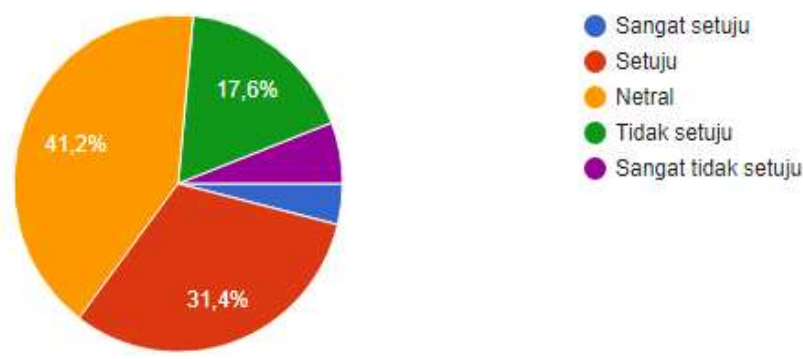

Gambar 10. Keberanian Mahasiswa

Berdasarkan Gambar 10 terkait pernyataan: "Saya lebih berani dan percaya diri melalui perkuliahan secara daring". Sebanyak 41,2\% responden menyatakan netral, 31,4\% responden menyatakan setuju, 17,6\% responden menyatakan tidak setuju, 3,9\% responden menyatakan sangat setuju, dan 5,9\% responden menyatakan sangat tidak setuju. Dari data yang diperoleh, mahasiswa memiliki kecenderungan netral terkait keberanian dan rasa percaya diri melalui perkuliahan secara daring.
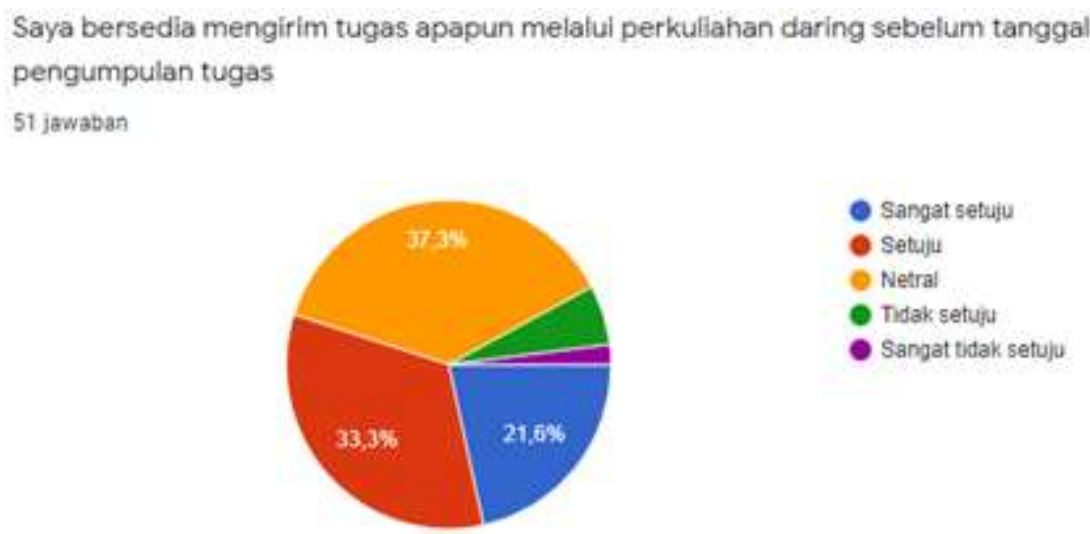

Gambar 11. Tugas Mahasiswa

Berdasarkan Gambar 11 terkait pernyataan: "Saya bersedia mengirim tugas apapun melalui perkuliahan daring sebelum tanggal pengumpulan tugas". Sebanyak 37,3\% responden menyatakan netral, 33,3\% responden menyatakan setuju, 21,6\% menyatakan sangat setuju, 5,9\% responden menyatakan tidak setuju, dan $2 \%$ responden menyatakan sangat tidak setuju. Dari data yang diperoleh, mahasiswa memiliki kecenderungan setuju terkait pengiriman tugas melalui perkuliahan daring secara tepat waktu.

\section{Dimensi Interaksi Mahasiswa}

Interaksi mahasiswa sangat penting dalam proses perkuliahan baik antara mahasiswa dengan mahasiswa maupun antara mahasiswa dengan dosen untuk membangkitkan semangat belajar, sehingga pada akhirnya mahasiswa dapat menggapai hasil yang maksimal. Interaksi mahasiswa dengan mahasiswa dan mahasiswa dengan dosen harus selalu dibangun untuk meningkatkan komunikasi dan diskusi tentang setiap kegiatan dalam proses perkuliahan (Lin \& Lin, 2015).

Sebagai contoh, bila seorang mahasiswa tidak memahami sebuah pertanyaan atau konsep, ia dapat bertanya kepada dosen untuk menjelaskan permasalahan tersebut hingga ia mengerti dan 
sebaliknya, bila dosen yang menjelaskan tersebut ada permasalahan maka ia dapat bertanya kepada dosen lain. Interaksi tersebut harus tetap terjaga karena dapat membantu mereka mencapai hasil belajar yang maksimal

Dosen selalu menjawab pertanyaan saya secara jelas dan tepat saat perkuliahan daring

51 jawaban
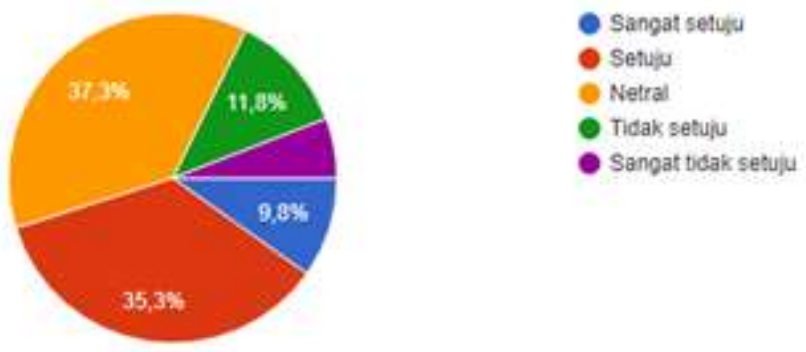

Gambar 12. Pertanyaan Mahasiswa

Berdasarkan Gambar 12 terkait pernyataan: "Dosen selalu menjawab pertanyaan saya secara jelas dan tepat saat perkuliahan daring". Sebanyak 37,3\% responden menyatakan netral, $35,3 \%$ responden menyatakan setuju, $11,8 \%$ responden menyatakan tidak setuju, $9,8 \%$ responden menyatakan sangat setuju, dan 5,8\% responden menyatakan sangat tidak setuju. Dari data tersebut, kecenderungan siswa menyatakan netral kearah setuju terkait jawaban pertanyaan yang dijawab secara jelas dan tepat oleh dosen dapat membantu mahasiswa dalam belajar.

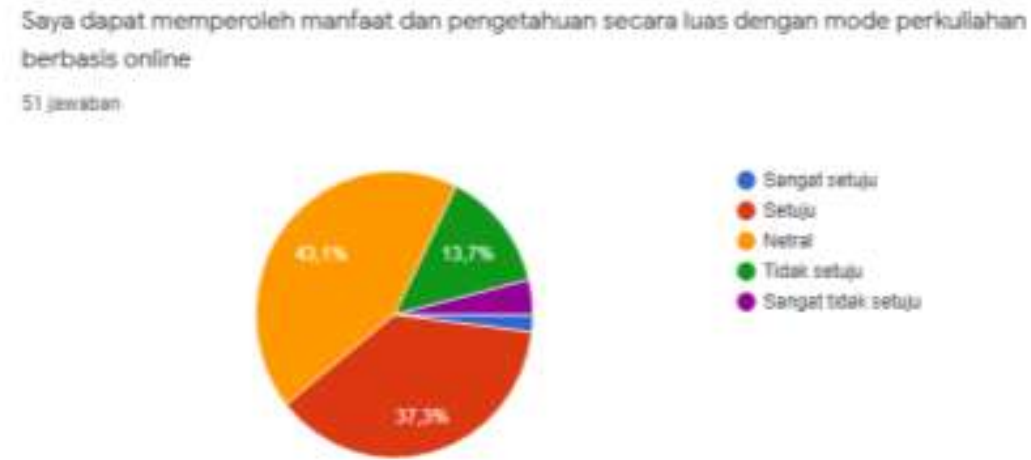

Gambar 13. Manfaat Pekuliahan Daring

Berdasarkan Gambar 13 terkait pernyataan: "Saya dapat memperoleh manfaat dan pengetahuan secara luas dengan mode perkuliahan secara daring". Sebanyak 43,1\% responden mengatakan netral, 37,3\% responden menyatakan setuju, $13,7 \%$ responden mengatakan tidak setuju, 3,9\% responden menyatakan sangat tidak setuju, dan $2 \%$ responden menyatakan tidak setuju. Berdasarkan data tersebut, mahasiswa memiliki kecenderungan setuju bahwasannya perkuliahan daring dapat memberikan manfaat dan pengetahuan secara luas. 
Interaksi antar anggota kelas sulit ketika perkuliahan daring

51 jawaban

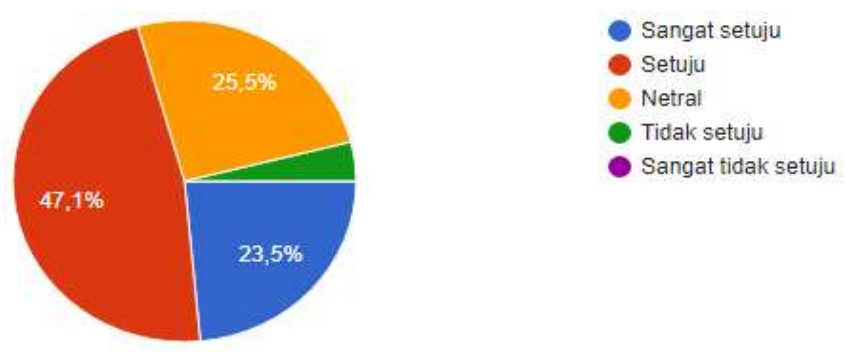

Gambar 14. Interaksi Mahasiswa

Berdasarkan Gambar 14 terkait pernyataan: "Interaksi antar anggota kelas sulit ketika pembelajaran daring". Sebanyak 47,1\% responden menyatakan Setuju, 25,5\% responden menyatakan netral, $23,5 \%$ responden menyatakan sangat setuju, dan 3,9\% responden menyatakan tidak setuju. Berdasarkan data tersebut, mahasiswa menyatakan bahwa sulitnya untuk berinteraksi dengan teman-teman dan dosen pada saat perkuliahan daring.

Saya berpartisipasi secara aktif dalam diskusi secara online
51 jawaban

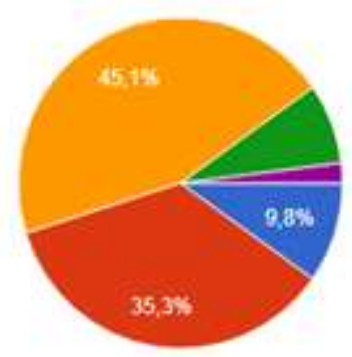

- Sangat setulu

- Setuja

C Netra:

- Tidak setuju

- Sangat tidak setuju

Gambar 15. Partisipasi Mahasiswa

Gambar 15 terkait pernyataan: "Saya berpartisipasi secara aktif dalam diskusi perkuliahan daring". Sebanyak 45,1\% responden menyatakan netral, 35,3\% responden menyatakan setuju, $9,8 \%$ responden menyatakan tidak setuju, $7,8 \%$ responden menyatakan tidak setuju, dan $2 \%$ responden menyatakan sangat tidak setuju. Berdasarkan data tersebut, mahasiswa menyatakan bahwa sebagian besar mereka setuju ikut berpartisipasi secara aktif pada saat perkuliaan daring berlangsung.

Saya dapat memperoleh pengetahuan dan wawasan baru dari pembelajaran online 51 jawaban
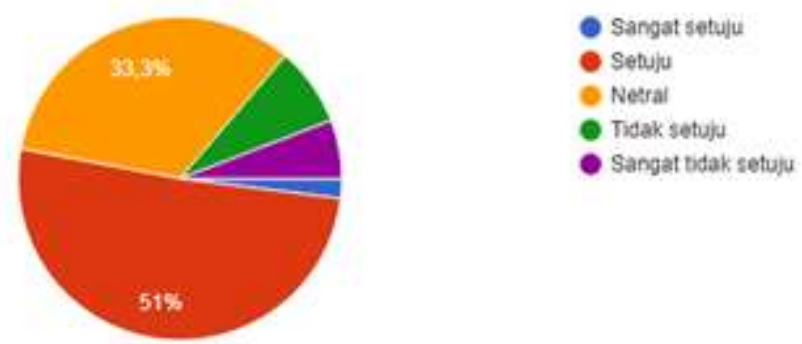

Gambar 16. Pengetahuan dan Wawasan Mahasiswa 
Berdasarkan Gambar 16 berikut pernyataan: "Saya dapat memperoleh pengetahuan dan wawasan baru dari pembelajaran daring". Sebanyak 51\% responden menyatakan setuju, 33,3\% responden menyatakan netral, 7,8\% responden menyatakan tidak setuju, 5,9\% responden menyatakan sangat tidak setuju, dan 2\% responden menyatakan sangat setuju. Berdasarkan data tersebut, mahasiswa menyatakan bahwasanya mereka banyak memperoleh tambahan wawasan baru selama proses perkuliahan daring berlangsung.
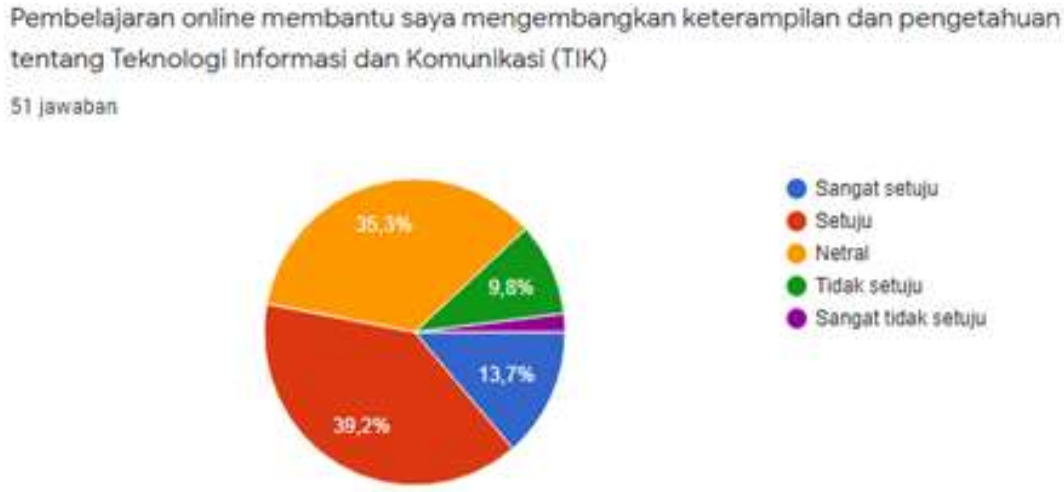

Gambar 17. Perkembangan Pengetahuan tentang TIK

Berdasarkan Gambar 17 terkait pernyataan: "Pembelajaran online membantu saya mengembangkan keterampilan dan pengetahuan tentang Teknologi Informasi dan Komunikasi (TIK)". Sebanyak 39,2\% responden menyatakan setuju, 35,3\% responden menyatakan netral, $13,7 \%$ responden menyatakan sangat setuju, 9,8\% responden menyatakan tidak setuju, dan $2 \%$ responden menyatakan sangat tidak setuju. Dari data tersebut diketahui bahwasannya mahasiswa memiliki kecenderungan setuju terkait pernyataan bahwa perkuliahan daring dapat meningkatkan keterampilan dan pengetahuan siswa tentang Teknologi Informasi dan Komunikasi.

\section{Simpulan}

Proses belajar dari rumah melalui perkuliahan daring yang merupakan manifestasi dari program pendidikan jarak jauh walapun belum dapat dikatakan ideal telah memberikan dampak yang cukup relevan terhadap pentingnya penguasan dan penggunaan teknologi informasi dalam dunia pendidikan. Meskipun disadari bahwa tantangan perkuliahan daring lebih bersifat teknis seperti terkait bahan ajar, kondisi lingkungan dan interaksi dalam proses pembelajaran. Namun disisi lain kemampuan menumbuhkan pembelajaran yang bermakna menjadi suatu hal yang urgent untuk dipenuhi. Terpenuhi seluruh aspek yang dapat mendukung dan membentuk mahasiswa yang ideal tentu sudah menjadi keharusan dan kewajiban bagi kita semua dalam menghadapi semakin kuatnya arus perkembangan teknologi informasi dan komunikasi..

\section{Referensi}

Alhogbi, B. G. (2017). Konsep Efektivitas. Journal of Chemical Information and Modeling, 53(9), 2125.

Archika, N. D. (2020). Makalah Corona Virus Disease-19. https://doi.org/10.31219/osf.io/vydbg 
Darmalaksana, W., Hambali, R., Masrur, A., \& Muhlas, M. (2020). Analisis pembelajaran online masa wfh pandemic covid-19 sebagai tantangan pemimpin digital abad 21. Karya Tulis Ilmiah (KTI) Masa Work. From Home (WFH) Covid-19 UIN Sunan Gunung Djati Bandung, 1-12.

He, W., Xu, G., \& Kruck, S. E. (2014). Online IS education for the 21 st century. Journal of Information Systems Education, 25(2), 101-106.

Hikmat, H., Hermawan, E., Aldim, A., \& Irwandi, I. (2020). Efektivitas pembelajaran daring selama masa pandemi Covid-19: Sebuah survey online. LP2M.

Huda, M., Maseleno, A., Teh, K. S. M., Don, A. G., Basiron, B., Jasmi, K. A., Mustari, M. I., Nasir, B. M., \& Ahmad, R. (2018). Understanding Modern Learning Environment (MLE) in Big Data Era. International Journal of Emerging Technologies in Learning, 13(5).

Irawan, H. (2020). Inovasi Pendidikan Sebagai Antisipasi Penyebaran COVID-19. Bengkulu: Ombudsman RI.

Kamayanthy, D. Y. (2020). Analisis Pembelajaran Menggunakan Edmodo Pada Mata Pelajaran Kewirausahaan Kelas Xii Dpib Di Smkn 1 Majalengka Tahun Ajaran 2020-2021. Journal of Chemical Information and Modeling, 1689-1699.

Kemendikbud. (2020). Data Pokok Pendidikan. Direktorat Jenderal Pendidikan Anak Usia Dini, Pendidikan Dasar dan Pendidikan Menengah.

Mardiasmo. (2017). Perpajakan Edisi Terbaru.

Maulana, H. A., \& Hamidi, M. (2020). Persepsi mahasiswa terhadap pembelajaran daring pada mata kuliah praktik di pendidikan vokasi. Equilibrium: Jurnal Pendidikan, 8(2), 224-231.

Muchtar, I. H., \& Muntafa, F. (2015). Efektivitas FKUB dalam Pemeliharaan Kerukunan Umat Beragama. Jakarta: Puslitbang Kemenag.

Rusdiana, E., \& Nugroho, A. (2020). Respon mahasiswa pada pembelajaran daring bagi mahasiswa mata kuliah pengantar hukum Indonesia UNESA. Integralistik, 31(1), 1-12.

Sanjaya, R. (2020). 21 Refleksi Pembelajaran Daring di Masa Darurat. SCU Knowledge Media.

Sugiyono, P. D. (2017). Metode Penelitian Bisnis: Pendekatan Kuantitatif, Kualitatif, Kombinasi, dan R\&D. Penerbit CV. Alfabeta: Bandung.

Sujadi, E., Fadhli, M., Meditamar, M. O., Kamil, D., Jamin, A., Yandri, H., \& Indra, S. (2021). Generalized anxiety disorder associated with individual work performance of Indonesian medical personnel during COVID-19 outbreak. International Journal of Public Health Science, 207-214.

Widiyarta, A., \& Jayusman, T. A. I. (2017). Efektivitas Program Pos Pembinaan Terpadu (Posbindu) Penyakit Tidak Menular (PTM) di Desa Anggaswangi Kecamatan Sukodono Sidoarjo. Dinamika Governance: Jurnal Ilmu Administrasi Negara, 7(2).

Widiyono, A. (2020). Efektifitas perkuliahan daring (online) pada mahasiswa pgsd di saat pandemi covid 19. Jurnal Pendidikan, 8(2), 169-177.

Yandri, H., Juliawati, D., \& Rusliah, N. (2020, October). Analisis stres masyarakat Kerinci ditinjau dari intensitas akses informasi pandemi COVID-19 (Stress Analysis of Kerinci Community in Terms of Access Information Intensity of COVID-19 Pandemic). In National Conference on Psychosmart.

A.M. Мамонтов, E. O. P. (n.d.). 済無No Title No Title. Jurnal Ilmu Administrasi Negara, 53(9), 1689-1699. 